\title{
Radiocarbon Dating of Lacustrine Strands in Arctic Alaska
}

\author{
CHARLES E. CARSON ${ }^{1}$
}

\begin{abstract}
Present exposures of lacustrine shelves 10 to 12 miles inland from the arctic coast of Alaska occur in response to intersection and draining by tundra streams. Near Point Barrow, these surfaces require 10 to 20 years for revegetation in today's climate. Many relict lakes in the area are surrounded by a stabilized sequence of 2 to 4 ancient strands, which suggests that in previous times more common regional piracy may have occurred.

Dates from 30 radiocarbon samples indicate the majority of relict strands are less than 3,500 years old, but with such a limited number of dates, neither equivalent levels nor similar sequences can establish clear time-correlation. However, the data perhaps suggest that lacustrine expansion reached a maximum near the end of the hypsithermal around 3,500-4,000 years ago and that the onset of the post-hypsithermal cooling phase corresponds in time with the initial period of draining.
\end{abstract}

RÉSUMÉ. Radiodatations de plages soulevées dans l'Alaska arctique. C'est par capture et drainage que les cours d'eau de la toundra provoquent l'apparition des banquettes lacustres actuelles, à 10-12 milles $(16-19,3 \mathrm{~km})$ à l'intérieur de la côte arctique de l'Alaska. Près de Point Barrow, ces surfaces demandent, sous le climat actuel, de 10 à 20 ans pour se recouvrir de végétation. Les nombreux lacsreliques de la région sont entourés par une séquence stabilisée de deux à quatre plages soulevées, ce qui suggère qu'aux époques précédentes, le phénomène de la capture régionale a pu être plus fréquent.

Les trente échantillons radiodatés indiquent que la majorité des plages soulevées ont moins de 3500 ans; mais avec un nombre aussi limité de datations, ni les nivaux équivalents ni les séquences similaires ne peuvent indiquer une corrélation chronologique claire. Cependant, ces données suggèrent que l'expansion lacustre a atteint un maximum vers la fin de l'hypsithermal - environ 3500-4000 ans av.p. - et que le début de la phase de refroidissement post-hypsithermal correspond dans le temps avec le début de la période de drainage.

РЕЗЮМЕ. Датировка озерных беретов в аркіической зоне Аляски, радиоуалеродным меtодом. Выходы древних озерных берегов в 10-12 милях от арктического побережья Аляспи образовались в результате пересечения тундровых рек и дренирования. В условиях современного климата, для восстановления растительного покрова на этих поверхностях в районе Пойнт Барроу требуется 10-20 лет. Многие из реликтовых озер имеют четко выраженные террасы, состоящие из 2-4 древних берегов. Это позволяет предположить, что в прошлом региональный захват, возможно, происходил чаще.

Данные, полученные на основании 30 радиоуглеродных проб, указывают на то, что возраст больпинства реликтовых берегов менее 3500 лет. Этих данных недостаточно, чтобы составить полную картину образования берегов. во времени. Однако можно предположить, что расширение площади озер достигл максимума в конце гипсиктермальной стадии около 3500-4000 лет тому назад, и что начало постгипситермальной фазы совпадает во времени с началным периодом дренирования.

\section{INTRODUCTION}

Consistent rings of 2 to 4 exposed and revegetated wave-cut shelves surround many lakes developed in the Late Pleistocene Gubik Formation (Payne et al.

${ }^{1}$ Assistant Professor, Department of Geology, University of Minnesota. 




FIG. 1. Oblique aerial photo of recently exposed shelves around a lake west of Point Barrow.

1951) on the Alaskan Arctic Coastal Plain. At present, intersection by headward eroding streams in the ice-rich surficial formation in which these basins have developed permits occasional partial draining and shelf exposure (Fig. 1). But the more widespread and consistent number of relict surfaces suggest regional correlative cycles of piracy due to minor shifts in climate and eustatic level, crustal stability in Late Pleistocene time, or both. Thirty radiocarbon samples taken from these abandoned strands show the highest levels to be between 2,700 and 3,500 years old. The most recent surfaces, just above present water levels, are between 700 and 1,600 years old. The samples were taken from 4 characteristic bàsin sequences near Point Barrow (Fig. 2, A to D).

The composite age of tundra peats on these revegetated surfaces and the complex stratigraphy left by a transgressive-regressive lacustrine cycle (the "ThawLake Cycle" of Britton 1957) make sampling and analysis subject to error, and



FIG. 2. Sketch map of the

Point Barrow area showing Sequences A to D. Ikroavik Lake is marked " $E$ ". 
data from only 4 sequences are not statistically significant. Results so far indicate that each strand sequence originated within the post-hypsithermal cooling phase; to conclude more is speculative. However, since this type of investigation is expensive and time-consuming, and since it may be some time before further work is undertaken, it seems advisable to make present results available. The concluding suggestions regarding correlation and regional history are made to provoke interest and comment.

\section{THE LACUSTRINE CYCLE}

Near Point Barrow, large, mature lakes are 1 to 3 miles long and roughly $1 / 4$ to $1 \frac{1 / 2}{2}$ miles wide; they are seldom more than 10 feet deep because thaw is limited by a sharply decreasing ice content in the first 20 to 30 feet below the surface of the ground (Carson and Hussey 1962). There are many other lakes and drained lake basins, however, in all size ranges and stages of development, including numerous overlapping sequences showing a cyclic pattern.

Thaw-ponds begin in poorly drained sites or where surface sod has been removed exposing permafrost. With successive seasons, persistent pools gradually expand and deepen, primarily through thaw of the ice beneath, with some erosion around the margins. Later, wave action tends to elongate the basins in the directions of the prevailing easterly and westerly winds. This may be considered to be the transgressive youthful stage. In the 1,200- to 1,500-foot fetch range, however, owing to buffering and insulating effects of wave-built bars, and the restrictive influence of developing equilibrium profiles along the sides, basin dimensions become equal and many square or rectangular lakes appear. From this point until full maturity, the forces of beach-drifting, longshore currents, and thaw are primarily effective at the ends, and basins gradually become elongated in a northsouth direction (Carson and Hussey 1960, 1962).

With increasing size, there is more probability of coalescence with adjacent basins, intersection by tundra streams, or migration into areas of coarser sedi-

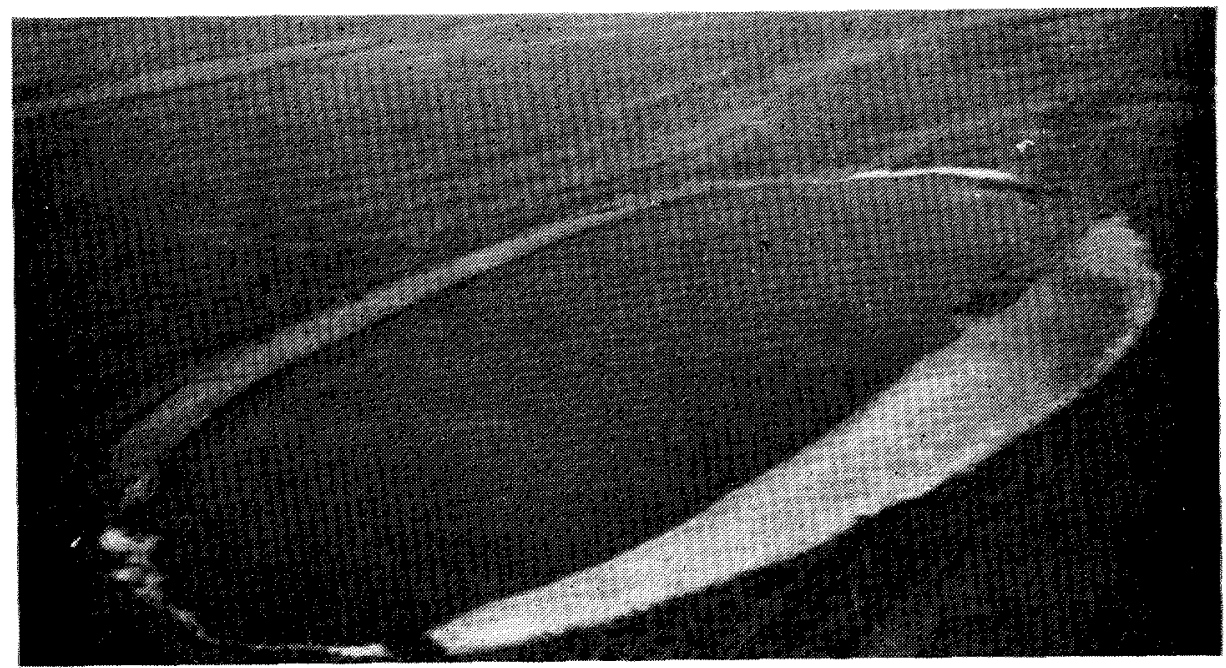

FIG. 3. Revegetated Lower and Middle shelves on the west side of Sequence A. 
ments, all factors that can initiate a draining, regressive, old-age phase. As the water recedes, wave-cut shelves are left as exposed strands which, in the present climate, are observed to revegetate in 10 to 20 years. During subsequent stable water levels, thaw settlement occurs and new equilibrium profiles are constructed at lower levels so that later drainings result in terraced sequences of shelves (Fig. 3). These strands are sometimes separated by barrier beaches behind which a secondary cycle of ponding begins (Carson 1961). With time, an original lake may be confined to the old central basin of the ancestral lake as a long, narrow strip of water between shelf sequences, and may eventually disappear. Meanwhile, the expansion and coalescence of new ponds on surrounding shelves begins another cycle.

Intensive reworking of the Gubik surface near Point Barrow by lacustrine processes, and the resulting surficial stratigraphy, are often unrecognized or misinterpreted. It is probable that more than 75 per cent of this area has been affected by the lacustrine cycle. Areas of so-called primary or upland tundra (some of which, in coastal areas, are marine beaches), are largely restricted to narrow

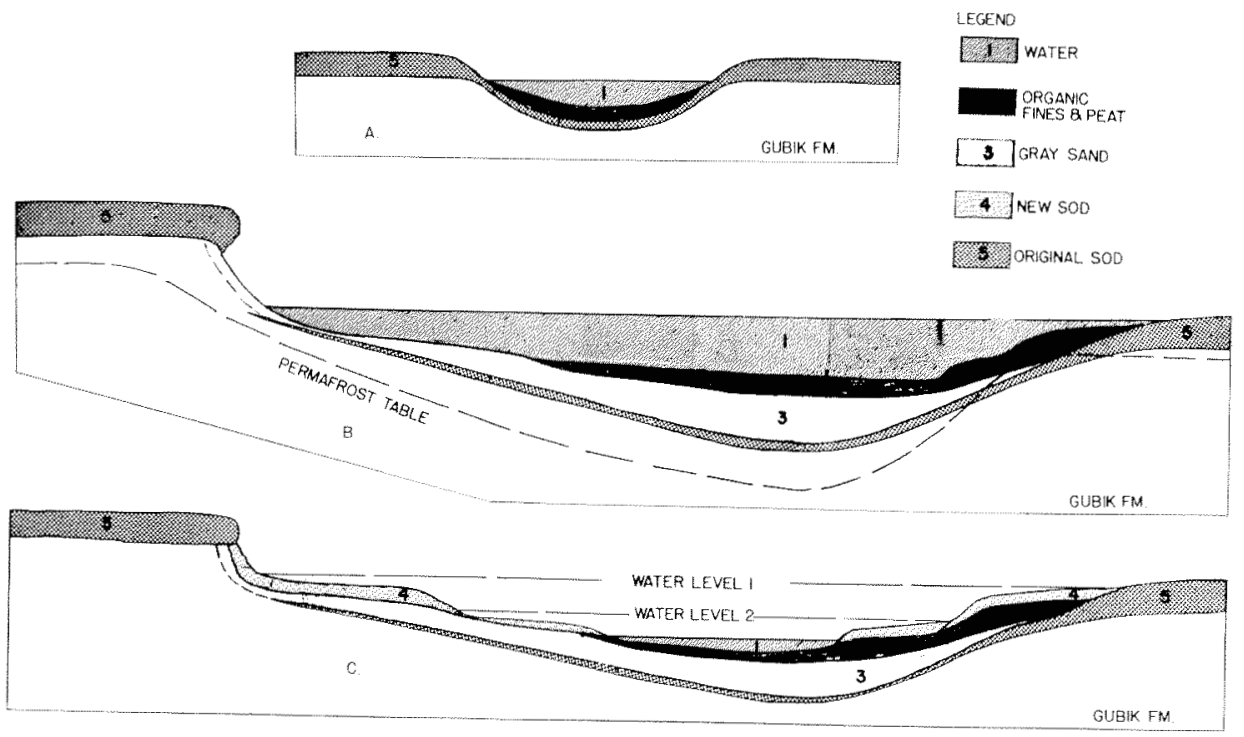

FIG. 4. A generalized cross-section sequence of the thaw-lake cycle from youth (A) through maturity $(B)$ to old age $(C)$.

wreaths of ridges around basin sequences. They are made up of poorly sorted silts, sands, and gravels. However, beneath the extensive lacustrine surfaces are definite stratigraphic horizons (Fig. 4). In small ponds, sediments are mostly organic silts in a mantle over a submerged tundra mat. In mature basins, sand beaches occur below wave-cut banks and peat bars along shores of lower relief. In the middle, 1 to 2 feet of dark organic silts overlie well-sorted, fine gray silt and sand in a well-defined contact, the two having been winnowed apart by waves due to density differences. The sand is seldom more than 2 to 4 feet thick and grades downward into tundra peat remnants from the transgressive phase of the ancestral lake. 
In the idealized stratigraphic evolution, surface mats of sod should be consistently younger towards the centres of basins in the regressive phase; that is, upper shelves should be older than lower shelves. Conversely, samples from buried mats of the transgressive phase should be older towards the centres of the original basins. These trends, however, are difficult to demonstrate for the following reasons:

1) Reworked organic matter from the eroded older tundra surface causes peat samples to be weighted in favour of older than actual ages by a factor proportionate to the amount of reworked material they contain. Samples from relict peat bars or from highly organic materials of former central basins are examples. Those from former zones of scour, where there is relatively little previous organic material, are probably the best.

2) Secondary ponding on older shelves creates reworked sediments as younger sites surrounded by, and lying upon, older tundra, and sediments with overlying peats left by secondary ponds are often hard to distinguish from those of the older main strand. Should tertiary ponding occur, buried secondary profiles may be mistaken for original sunken mat of the transgressive phase and samples will yield erroneous ages.

3) The peculiarities of the hydrodynamic systems which control basin morphology (Carson and Hussey 1960, 1962), cause the basins and basin sequences to be asymmetrical, both in cross-profile and in long profile. For example, shelves on the west sides are generally as much as 20 to 30 per cent wider and are of a gentler slope than those on the east; a unit drop in water level will therefore expose greater lateral expanses of the west shelves. Hence, sample sites must be spaced carefully on each side of a basin to be certain that they represent the same level. However, the asymmetry of some basins may be reversed due to their coalescence.

\section{SAMPLE SITES AND C-14 DATES}

The basin sequences sampled in this investigation occur 10 to 15 miles south and east of Barrow Base and are designated simply A, B, C, and D (Fig. 2). The base of the present tundra peat mat, buried mats, and drifted peat were all sampled (Fig. 5). The locations and numbers of the samples are shown in Figs. 6 to 9 and the data summarized in Table 1.

The majority of samples were from the base of the surface sod and these were treated with $\mathrm{HCl}$ and $2 \mathrm{~N} \mathrm{NaOH}$. As is well known, peats are among the more difficult organic materials upon which to base C-14 interpretations. Annual dilution produces material of composite age, in both surface and buried mats. With both types, treating and dating of the decay-produced humic acid (alkali-soluble) gives an older date, presumably representing a smaller age range. In this investigation, although all surface peats were treated, most buried mats were not, and more surface than buried peats were sampled since they are often easier to associate with definite surfaces, and sampling of buried peats requires extensive trenching to be certain the samples have not been recycled but actually represent continuous mats of original transgressed tundra. 




TABLE 1.
FIG. 5. Soil monolith from a C-14 sample site showing the sharp contact between wellsorted gray beach sand and the overlying peat sod.

Carbon-14 dates of Samples 1-30 showing the stratigraphic origin and treatment applied.

\begin{tabular}{|c|c|c|c|c|c|c|c|c|}
\hline \multicolumn{3}{|c|}{$\begin{array}{l}\text { Sample numbers and } \\
\text { dates in years B.P. }\end{array}$} & \multirow{2}{*}{$\begin{array}{c}\begin{array}{c}\text { Laboratory } \\
\text { number }\end{array} \\
\text { GX0234 }\end{array}$} & \multirow{2}{*}{$\begin{array}{c}\begin{array}{c}\text { Frozen or } \\
\text { thawed }\end{array} \\
\mathrm{T}\end{array}$} & \multirow{2}{*}{$\begin{array}{c}\begin{array}{c}\text { Sample } \\
\text { depth }\end{array} \\
4-5^{\prime \prime}\end{array}$} & \multirow{2}{*}{$\begin{array}{c}\begin{array}{c}\text { Thickness of } \\
\text { peat layer }\end{array} \\
5^{\prime \prime}\end{array}$} & \multirow{2}{*}{$\begin{array}{c}\begin{array}{c}\text { Treated base } \\
\text { of surface sod }\end{array} \\
\mathrm{X}\end{array}$} & \multirow[t]{2}{*}{$\begin{array}{c}\text { Untreated } \\
\text { buried sod }\end{array}$} \\
\hline 1 & $2695=$ & +115 & & & & & & \\
\hline 2 & 695 & 95 & GX0235 & $\mathbf{T}$ & $5-6^{\prime \prime}$ & $6 " 1$ & $\mathbf{x}$ & \\
\hline 3 & 2055 & 70 & GX0236 & $\mathbf{T}$ & $9-10^{\prime \prime}$ & $10^{\prime \prime}$ & $\mathbf{x}$ & \\
\hline 4 & 1865 & 160 & GX0237 & $\mathbf{T}$ & $4-5^{\prime \prime}$ & $5^{\prime \prime}$ & $\mathbf{x}$ & \\
\hline 5 & 2705 & 150 & GX0075 & $\mathbf{F}$ & $6-7^{\prime \prime}$ & $2^{\prime \prime}$ & $x$ & \\
\hline 6 & 1200 & 180 & GX0076 & $\mathbf{T}$ & $5-6^{\prime \prime}$ & $6^{\prime \prime}$ & $\mathbf{x}$ & \\
\hline 7 & 1465 & 125 & GX0077 & $\mathbf{F}$ & $9-10^{\prime \prime}$ & $4^{\prime \prime}$ & & $\mathbf{x}$ \\
\hline 8 & 475 & 125 & GX0078 & $\mathbf{T}$ & $5-6^{\prime \prime}$ & 6" & $\mathrm{x}$ & \\
\hline 9 & 1770 & 160 & GX0079 & $\mathrm{T}$ & $9-10^{\prime \prime}$ & $3 "$ & $\mathrm{X}$ (Drift)* & \\
\hline 10 & 715 & 210 & GX0079 & $\mathbf{T}$ & $9-10^{\prime \prime}$ & $3^{\prime \prime}$ & & X (Drift) \\
\hline 11 & 1795 & 65 & GX0238 & $\mathrm{T}$ & $3-4^{\prime \prime}$ & $4^{\prime \prime}$ & $\mathbf{x}$ & \\
\hline 12 & 820 & 95 & GX0239 & $\mathbf{T}$ & $5-6^{\prime \prime}$ & $6^{\prime \prime}$ & $\mathrm{x}$ & \\
\hline 13 & 1620 & 60 & GX0240 & $\mathrm{T}$ & $3-4^{\prime \prime}$ & $4^{\prime \prime}$ & $\mathrm{x}$ & \\
\hline 14 & 2770 & 90 & GX0241 & $\tilde{T}$ & $3-4^{\prime \prime}$ & 4" & $\mathrm{x}$ & \\
\hline 15 & 945 & 115 & GX0080 & $\mathbf{F}$ & $14^{\prime \prime}$ & $3^{\prime \prime}$ & & $\mathbf{X}$ (Drift) \\
\hline 16 & 2195 & 110 & GX0081 & $\mathbf{F}$ & $6-7^{\prime \prime}$ & $2^{\prime \prime}$ & & \\
\hline 17 & 395 & 150 & GX0082 & $\mathbf{T}$ & $5-6^{\prime \prime}$ & $6^{\prime \prime}$ & $\mathrm{x}$ & \\
\hline 18 & 1540 & 115 & GX0083 & $\overline{\mathbf{F}}$ & $9-10^{\prime \prime}$ & $4^{\prime \prime}$ & & $\mathbf{x}$ \\
\hline 19 & 1395 & 135 & GX0085 & $\mathbf{T}$ & $7-8^{\prime \prime}$ & $8^{\prime \prime}$ & $x$ & \\
\hline 20 & 4865 & 150 & GX0084 & $\mathbf{F}$ & $7-8^{\prime \prime}$ & $8^{\prime \prime}$ & & $\mathbf{x}$ \\
\hline 21 & 3345 & 110 & GX0242 & $\mathrm{T}$ & $3-4^{\prime \prime}$ & $4^{\prime \prime}$ & $x$ & \\
\hline 22 & 855 & 95 & GX0243 & $\mathbf{T}$ & $5-6^{\prime \prime}$ & $6^{\prime \prime}$ & $\mathrm{x}$ & \\
\hline 23 & 1540 & 105 & GX0444 & $\hat{\mathbf{T}}$ & $7-8^{\prime \prime}$ & $8^{\prime \prime}$ & $\mathrm{x}$ & \\
\hline 24 & 4280 & 160 & GX0445 & $\mathbf{T}$ & $9-10^{\prime \prime}$ & $10^{\prime \prime}$ & $\mathrm{x}$ & \\
\hline 25 & 1445 & 105 & GX0400 & $\mathbf{T}$ & $6-7^{\prime \prime}$ & $7^{\prime \prime}$ & $x$ & \\
\hline 26 & 1170 & 120 & GX0401 & $T$ & $5-6^{\prime \prime}$ & 6" & $x$ & \\
\hline 27 & 1240 & 130 & GX0402 & $\mathrm{T}$ & $5-6^{\prime \prime}$ & $6^{\prime \prime}$ & $\mathrm{x}$ & \\
\hline 28 & 2980 & 135 & GX0403 & $T$ & $6-7^{\prime \prime}$ & $7^{\prime \prime}$ & $\mathrm{x}$ & \\
\hline 29 & 975 & 95 & GX0404 & $\mathbf{T}$ & $5-6^{\prime \prime}$ & $6^{\prime \prime}$ & $\mathrm{x}$ & \\
\hline 30 & 780 & 100 & GX0405 & $\mathrm{T}$ & $4-5^{\prime \prime}$ & $5^{\prime \prime}$ & $x$ & \\
\hline
\end{tabular}

*Drift refers to material from buried peat bars in old shorelines. 
Sample sites were located using air photos and transects across basin sequences. However, equivalence of geomorphic position, stratigraphic position, and variations in the pattern of microrelief often required deviations from a systematic areal location of a sample net so that the desired regularity was not always achieved. The problems encountered are described in the discussion of each basin sequence.

Sample analysis was conducted by Geochron Laboratories of Cambridge, Massachusetts. The samples, consisting of decomposed and partially decomposed tundra vegetation typical of this area (Britton 1957), were washed and disaggregated. The peat was then brought to the boiling point in $1 \mathrm{~N} \mathrm{HCl}$ to dissolve any carbonates and to remove any metallic ions possibly interfering with alkali extraction of humic acids and other alkali soluble materials. After standing an hour, the acid solution was filtered and the peat washed. The sample was then transferred to a $2 \mathrm{~N} \mathrm{NaOH}$ solution and again brought to the boiling point, and held there for about 1 hour, to dissolve the alkali soluble material, primarily humic acids. The solution was then separated by decantation and filtration and the filtrate recovered. After this was acidified with phosphoric acid, flocculent precipitate of humic acid formed. At this point, any $\mathrm{CO}_{2}$ picked up from the atmosphere during the alkali extraction was evolved from the acid solution. The precipitate of humic acid was then vacuum-filtered, dried to a cake, combusted to $\mathrm{CO}_{2}$, and made ready for counting in the standard manner.

The samples were taken from the lowest layers in the surface peat mats. It is reasonable to expect that much of the material in these layers has been converted to alkali-soluble material; at the same time, it is probable that by comparison with this oldest material, the humic acid contribution of any modern vegetation is relatively minor. The problem lies in the vegetal contribution of intermediate age, which may be only partially decayed and partially converted to alkali-soluble material. In the present case, this contribution has been variable in both amount and age, so that it has been a prime factor in limiting the accuracy of any C-14 dates. For the first vegetation developed on strand exposure, the dates are therefore minimum ages. The amount by which they are too young depends upon the subsequent contribution of younger material in the base of the mat. Buried mats are also likely to produce dating error for the same reasons, because they are essentially composed of the same sort of material, even though long buried.

The significance of this for the correlation purpose of the investigation is that the dates are most likely to be uniformly too young, by how much is uncertain and probably variable. However, there was a great similarity, both in thickness and appearance, between all the surface mats sampled. If this can be taken to mean that conditions of formation were very similar (perhaps it cannot), the magnitude of age difference between samples of adjacent shelves is possibly more accurate than absolute dates of individual samples.

The samples were peats composed of the grasses, moss, and sedge typical of this area today (Britton 1957), though this conclusion is based on cursory examination only and no botanical investigation was carried out. Sample sites are shown in Figs. 6 to 9. 


\section{DISCUSSION}

\section{Sequence $A$}

Sequence A (Fig. 6) occurs north of the drainage from Ikroavik Lake (Fig. 2, E) to the sea. Both it and Sequence B to the south of the drainage were selected because they had well-developed strands and both were connected to the same drainage line. If the original lakes drained simultaneously in response to regional stream control, the ages of the strand sequences should correlate.

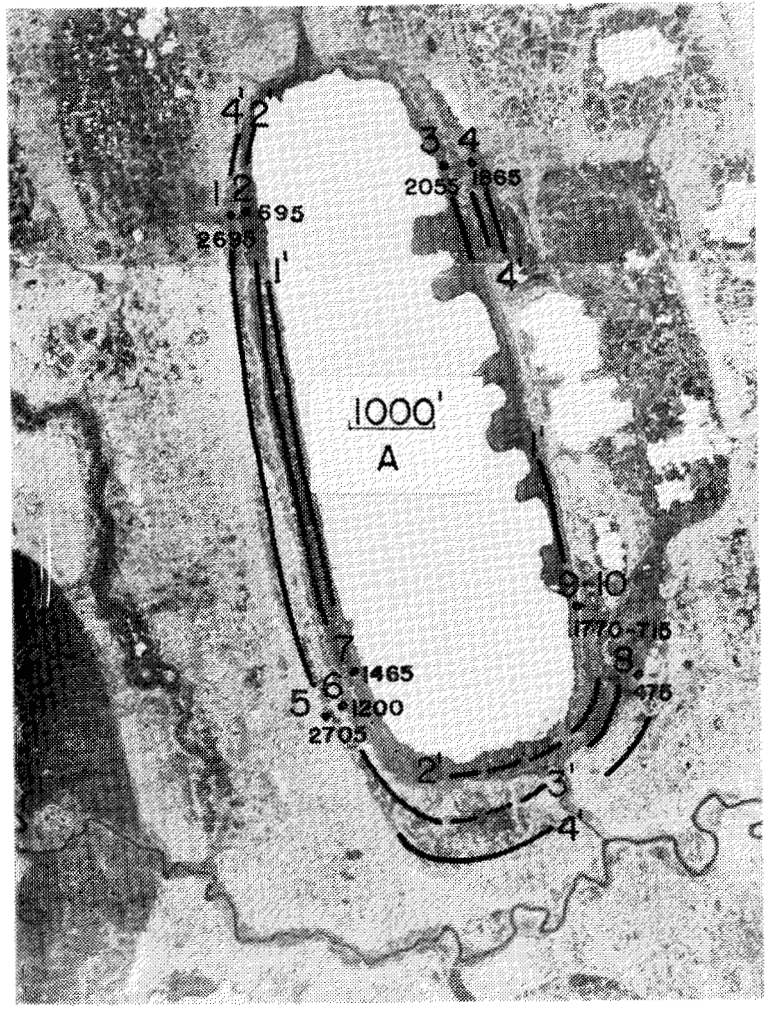

FIG. 6. Vertical aerial photo of Sequence $A$ showing numbered sample sites and dates.

Examination of Fig. 6 reveals that 2 strand or shelf areas surround the present lake: an outer light-coloured strip similar to the adjacent upland surface, and an inner, darker ring. Close observation shows a lower subdivision on the west side of the latter, and yet another more recent strand appearing as a very narrow strip next to the lake, which has an equivalent on the east side, including spit-like projections there. This lowest, third, and possibly fourth, shelf has counterparts around many of the larger lakes near Point Barrow. During spring melt-off, when lake levels are higher for a time, these features are obscured, but there is sufficient exposure during lower water levels in summer for this shelf to be vegetative. Presumably, it may represent the latest regional drop in water level.

Topographic contours on a 1-foot interval are superimposed on the photograph in Fig. 6. On the upper shelf on the west side of A, samples No. 1 and No. 5 show close agreement at about 2,700 B.P. The elevation of these above water level on 10 August 1963, was slightly over 4 feet. On the lower shelf along the west side, 
No. 2 dates at 695 B.P. The elevation is 2 feet above water level. At the south end, on the same side, No. 6 dates at 1,200 B.P. and the elevation is slightly higher than that of No. 2, being about 3 feet. No. 7, dating at 1,465 B.P., occurs on a lower subdivision of the same shelf at about the 2 -foot elevation. It is in reworked peat bar material and so is older than either No. 2 or No. 6 .

The upper shelf on Sequence A appears to continue around the north end to the east side, but along the middle and southern portions basin coalescence and recycling have occurred. At the north end, sample No. 4 yields a date of 1,865 B.P. Although this site was selected on what appeared to be a relatively old surface, it is possible that it was actually located along the obscure margin of a later, now relict, pond which appears as the darker area along the outer margin on the photograph. The date of No. 8 on the upper shelf at the south end is 475 B.P.; again, the photograph shows it to be in the site of more recent ponding. The elevation of both these samples was 4 feet. Sample No. 3 on the lower surface at the north end of the east side of A dates at 2,055 B.P. Its elevation is approximately 1 foot. At the same elevation at the south end, No. 9 dates at 1,770 B.P. No. 10 is the same material, but No. 9 was treated whereas No. 10 was not. This material was from a buried peat bar underlying the present sod, a bar formed when the lake stood at a slightly higher level than it does at present.

In summary, samples No. 1 and No. 5 from the well-drained upper surface along the west side show excellent agreement at 2,700 B.P. Dates on what appears to be the same surface on the east side, however, are inconclusive owing to recycling (Nos. 4 and 8). On the lower shelf on the west side, No. 6 at the 3-foot elevation is 1,200 years old, and No. 2 at the 2 -foot elevation is 695 years old. On what appears to be the equivalent surface across the lake, the ages of Nos. 3 and 9 (2,055 B.P. and 1,770 B.P.) are reasonably close together, but considerably older than No. 2 (695 B.P.), which is 1 foot higher and therefore should be older. A possible explanation is that coalescence of two adjacent lakes in the past allowed drainage and exposure of the eastern shore of the one on the east before drainage of the subsequent lake exposed the site at No. 2 . This would have occurred if the elevation of the one on the east had been slightly higher. The existence of several shallow projections along the east side of $\mathrm{A}$ indicate that this may very well have happened.

\section{Sequence $B$}

The upper shelf around Sequence B (see Fig. 7) dates at 1,795 B.P. at No. 11 and 2,195 B.P. at No. 16 on the west side. The elevation of No. 11 is 5 feet above lake level, and that of No. 16 is 6 feet above lake level. No. 16 was slightly higher in elevation than No. 11, and this, along with the fact that the sample was in buried sod of the transgressive phase, accounts for its somewhat older age. After the sod from No. 16 was submerged, the ancestral lake remained over the site 300 to 400 years before regression and revegetation at the time of No. 11 (which was from the base of the surface sod). No. 15 was taken from the margin of a revegetated secondary pond on the main strand, and clearly illustrates the effect superimposed younger materials may have on dating. The age of this sample is 945 B.P., and it is approximately the same elevation as No. 16 .

No. 12 on the west side is at 3 feet above lake level and dates at 820 B.P. 


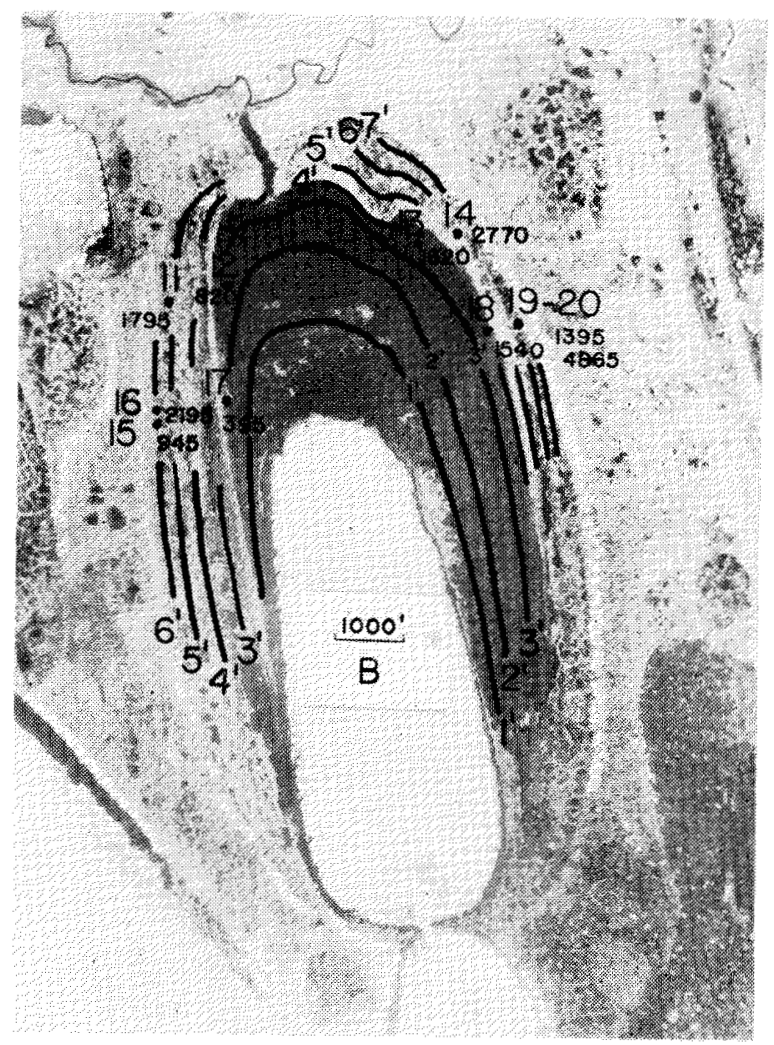

FIG. 7. Vertical aerial photo of Sequence $B$ showing numbered sample sites, dates, and contours above present lake level.

Farther down the same shoreline, and on the same lower surface but at only about 2-feet elevation, No. 17 dates at 395 B.P. Both of these samples were from the base of the surface sod.

On the upper shelf on the east side, No. 14 dates at 2,770 B.P. Its elevation is about 7 feet above lake level. Farther down the same shoreline, No. 19 dates at 1,395 at the base of the surface sod; the elevation is again about 7 feet. In the same site as No. 19 , sample No. 20 was buried peat of the transgressive phase, and dated at 4,865 B.P. No. 19 was in a comparatively wet spot and may have been secondary. On the lower shelf of the east side, No. 13, at elevation 4 feet, dates at 1,620 B.P. No. 18, at the same elevation on the same surface, is at fairly close agreement at 1,540 B.P.

In summary, samples from Sequence B are generally older on the east side, a circumstance probably related to basin history and shape, as in the case of Sequence A. The 2,770 B.P. date of No. 14 on the upper shelf of the east side is regarded as a good date for that surface. The site was well drained and apparently free from recycling or secondary pond superposition. Its elevation of 7 feet is, along with that of Nos. 19 and 20, the highest in the sequence, and presumably it drained first. The appearance of this upper surface, both on the ground and in the photograph, is quite similar to that of the upper shelf around Sequence $A$, and the date is just about the same. The upper shelf on the west side of $B$ is, in the position of the sample sites, a little lower ( 5 to 6 feet) and, judging by the dates, was probably drained somewhat later $(1,800$ to 2,200 B.P.). The basin (like 
Sequence A after coalescence) is somewhat reversed in its asymmetry, as the offcentre position of lake B shows. The deeper portion was on the west side, and this side is consistently exposed last.

Examination of the topographic contours in Fig. 7 shows sites No. 13 and No. 18 (1,620 and 1,540 B.P. respectively) at the same elevation being exposed at about the same time on the lower shelf on the east side. On the west side, the water had receded below site No. 12 before 820 B.P., and had passed below the 2-foot level of No. 17 before 395 B.P. The youngest site (No. 17) is closest to present water level, and was therefore the last to emerge. On this lower shelf, if the dates are accurate at least in relation to each other, we may have some idea of the length of time required for the lake to recede across the lower shelf to its present position - about 1,200 years. For whatever significance it may have, the dates on the lower surface of Sequence B are similar in order of magnitude to those of the lower surface on the west side of Sequence A.

\section{Sequence $C$}

In Sequence C (Fig. 8), the upper shelf on the west side dates at 3,345 B.P. at site No. 21; the elevation above the lake is 4 feet. The lower shelf on the same side, at site No. 22, elevation 2.5 feet, dates at 855 B.P. These dates are roughly of the same order of magnitude as those in similar positions in Sequences A and B. On the east side, the upper shelf dates at 4,280 B.P. at site No. 24, elevation 4 feet. The lower shelf dates at 1,540 B.P. at site No. 23, elevation 3 feet. There was a considerable proportion of sapropel in sample No. 24 from reworked organic fines of the ancestral basin and, thus, the age is older than might otherwise be expected. It may represent, in part, the transgressive phase. Since the site

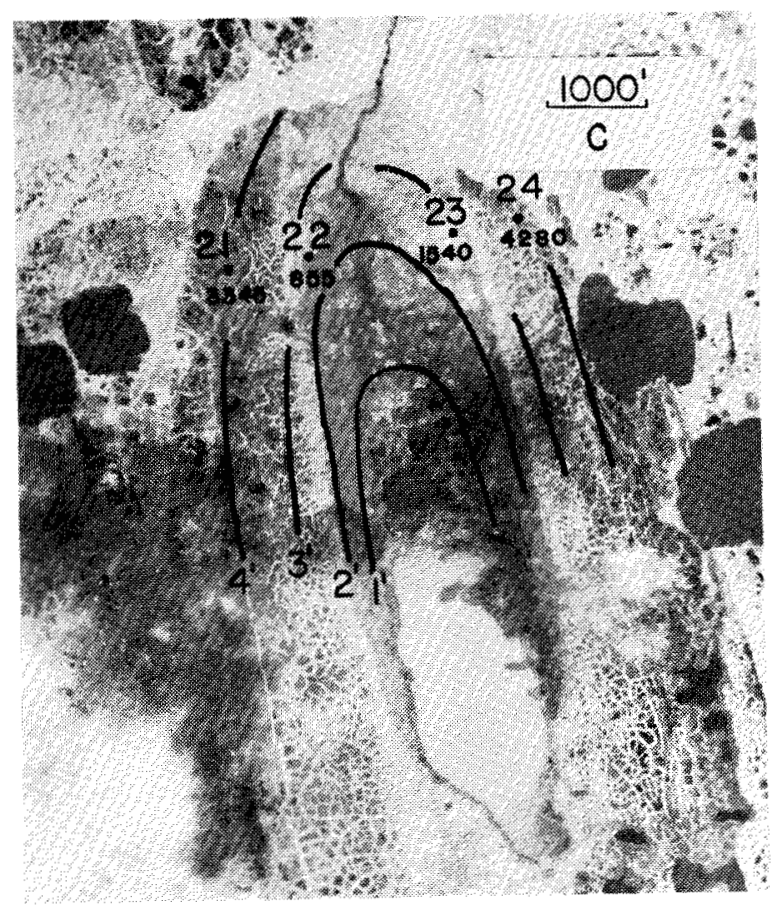

FIG. 8. Vertical aerial photo of Sequence $\mathrm{C}$ showing numbered sample sites and dates. 


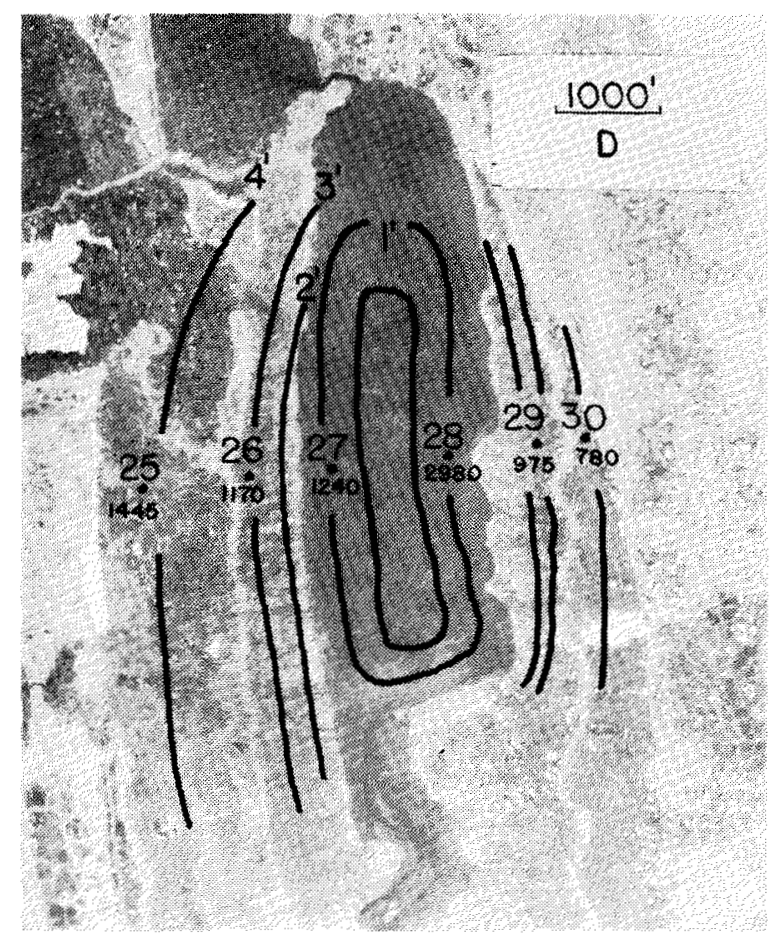

FIG. 9. Vertical aerial photo of Sequence $\mathrm{D}$ showing numbered sample sites and dates.

of No. 23 was exposed before that of No. 22, it is older by about 700 years. Site No. 23 is similar in position to those of Nos. 13 and 18 in Sequence B, and the age is the same.

\section{Sequence $D$}

The positions of sample sites on Sequence D are shown in Fig. 9. This sequence is asymmetrical in the manner typical of most modern lake basins near Point Barrow (Carson and Hussey 1962), and it possesses what appear to be very definite and uncomplicated shelves. However, as the data reveal, the ages of the shelves are not what might be expected, in either order of magnitude or sequence.

The age of No. 25, on the upper shelf on the west side, is older than that of No. 26 on the adjacent middle shelf. No. 25 dates at 1,445 B.P. and the elevation is about 4.5 feet; No. 26 dates at 1,170 B.P. and the elevation is 3 feet above the flat central basin. On the east side, the upper shelf at site No. 30 dates at 780 B.P.; elevation is 4 feet. This does not agree with the 975 B.P. date of site No. 29, the elevation of which is only 3 feet. Since the date of No. 29 is reasonably close to that of No. 26 on the equivalent shelf on the west side, it is assumed that No. 30 is in error. The age of 2,980 B.P. for No. 28, and that of 1,240 B.P. for No. 27 are probably both in error - transgressive phase sunken mat or organic fines from the basin of ancestral lake D having contaminated the sample. In fact, the very wide expanse of this sequence, for its shallow depth, probably means that all these samples are suspect for the same reason. Drainage of exposed strands was most likely very poor, and much older organic material remained from the old lake bottom to be incorporated into the new sod. This would be especially true 
for samples from the old central basin. However, since the effect of such contamination would be to increase the age of the samples, it may be that this sequence is much younger than the other three, since the dates, except for No. 28 , are of a fairly low order of magnitude.

\section{CONCLUSIONS}

The primary objective of this investigation was to demonstrate correlations between similar lacustrine surfaces. To do this, the stratigraphic basis for such correlation had to be established, and it was here that the investigation was most successful. The stratigraphic evolution proved to be complex in detail, as pointed out, but the overall picture of a transgressive-regressive cycle is fairly simple and systematic in outline (Fig. 4). The difficulty arose in attempting to make enough excavations to be certain of the general stratigraphy for a particular basin sequence. Because of this and the difficulties in dating peats, and because the number of dates was limited, a high degree of success cannot be claimed. However, the few dates available are suggestive, in the writer's opinion, of future regional correlations. For example, dates on the highest levels around Sequences A, B, and $C$ are very similar (2,700 to 3,345 B.P.), those at lower levels show a reasonable age succession with basin contours (Sequence B), and dates on the same levels show remarkably close agreement (Nos. 1 and 5, 13 and 18, and 11 and 16). Finally, anomalous dates are, for the most part, rather easily explained (see Discussion, pages 19 to 23 ).

On the basis of the evidence obtained so far, it is reasonable to suggest that lacustrine transgressive expansion reached a maximum during postglacial time, perhaps during the hypsithermal somewhere between 4,000 and 8,000 years ago. Generally rising sea level would have reduced stream gradients, thus reducing erosion, and producing ponding and beach ridges in the coastal areas of the nearly flat Arctic Coastal Plain. Warmer temperatures would have increased precipitation to an extent that most likely would not have been countered by evaporation in this northerly latitude, and this contributed to rising lake levels. With the onset of the post-hypsithermal cooling phase, about 3,500 years ago (Porter 1964; Brown 1965), minor reversals in the overall eustatic trend could well have initiated downcutting by coastal streams adjusting to lower base level. The surface gradient of the Coastal Plain near Point Barrow is less than 5 feet per mile, and this, along with permafrost sediments especially susceptible to erosion, provides a landscape which quickly reflects only slight changes in stream regimen, as rapid artificial draining of lakes in this area attests. Thus, perhaps the first of several regional cycles of basin intersection and draining began after 3,500 B.P.

It remains to show that sea-level changes of the sort suggested have occurred. As Shepard (1964) points out, there are several schools of thought regarding minor sea-level changes during postglacial time. The present writer's view is closest to that of Fairbridge (1960). Although the overall picture may have been one of rising sea level, it would seem that worldwide climatic changes affecting the relation between the amount of glacial ice on land, and sea level, have occurred during the postglacial, with consequent stabilizations and even minor reversals in the general rising trend. Fairbridge's curve shows fluctuations above and below present sea level for the last 6,000 years which are on the order of 10 to 12 feet. 
This curve shows a low sea level about 4,500 years ago followed by a high around 3,700 years ago and another low about 3,200 years ago, followed in turn by another high about 2,400 years ago, and another low about 1,500 years ago. The longer term trend has been a slight lowering during the last 6,000 years, after a sharp rise during the preceding 12,000 years. It remains to show whether these fluctuations had any effect on the lacustrine cycle near Point Barrow.

On the Arctic Coastal Plain near Point Barrow, a series of old beach ridges parallel to the present coast and 10 to 25 feet above it occur inland from the sea and form a connecting wreath around some coastal basin sequences. Radiocarbon dating of these is far from satisfactory, since the buried wood found in them has probably been reworked. Nevertheless, they must be older than the next highest levels below, that is, older than the uppermost lacustrine strands. For these beach ridges to have formed, the sea must once have stood higher than it does at present. That there has since been a withdrawal induced by eustatic or tectonic change seems obvious. In either case, a lowered base level would have occurred. That the most recent trend has been an advancing sea is indicated by marine intersection of numerous coastal lakes (Carson and Hussey 1962). It is possible that these features are of Sangamon age, though it is not likely since the Barrow coast is only a few tens of feet above sea level at most, and the sea-level fluctuations of Fairbridge's curve could well have produced them. Hume (1965), on the basis of radiocarbon dates on driftwood and artifacts from the beach ridges on Point Barrow itself, suggests a rise in sea level between A.D. 265 and $500(1,400$ and 1,700 B.P.) with a subsequent drop of about 2 metres below present level, followed by another rise between A.D. 1000 and 1100 (870 and 970 B.P.), with the present sea level almost 1 metre below the high-water levels. This appears to agree in part with Moore's work (1960) near Point Hope.

Brown (1965) has summarized the radiocarbon results of a number of previous investigators working near Point Barrow. He tentatively concludes that the gray silt layer of one drained basin is between 3,200 and 5,000 years old and that it was probably deposited as "windblown material." This gray layer exists below a foot or so of dark organic fines in all basins and lakes of any size near Point Barrow (Carson and Hussey 1961), and represents not a wind-laid deposit, but simply reworked Gubik sediments winnowed from lighter weight organic fines by normal wave processes (Fig. 4). Two samples he cites appear to have definitely come from below this gray layer and are probably from buried peat of the transgressive phase. They show close agreement at 3,540 \pm 300 B.P. (W-432) and $3,200 \pm 230$ B.P. (WI-1544). Brown's "Lake Series" consists of only 4 dates, but he suggests on this basis that a regional pattern in the thaw-lake cycle might exist and remarks on the difficulty of accurately dating lake peats, ending with the statement that "no attempt should be made to determine rates of deposition from such sampling and dating." The paper suggests that the majority of surfaces in the Point Barrow vicinity are less than 8,300 years old, and possibly younger, a very reasonable position since the majority of surfaces are lacustrine and these appear to be less than 3,500 years old.

Independent evidence, then, suggests minor falls in sea level superimposed on the general postglacial rise. The dates reported in this investigation do not match well with the first sea-level fall in Fairbridge's curve for the last 6,000 years, but 
the 2,700- to 3,300-year age of the upper shelves agrees with the second fall as do the 1,500- to 1,600-year dates for the first exposure of the lower shelves in Sequences $B$ and $C$. The 1,500- to 1,600-year dates also agree with Hume's work.

The writer has studied lakes, lacustrine processes, and basin sequences near Point Barrow since 1958, the present study being concluded in 1964. If anything is apparent, it is that dating of these geomorphic surfaces and events must be systematic and thorough. It is not enough to collect samples at random, and then theorize on the history of the entire Arctic Coastal Plain. The present paper simply bears this out. Although the investigation was attempted in as systematic and as thorough a manner as possible, the time and resources available were not nearly enough to shed more than a little light on a very complex problem.

\section{ACKNOWLEDGEMENTS}

The investigation reported in this paper was conducted under the auspices of the Arctic Institute of North America through a contract (ONR-332-337) with the Office of Naval Research, United States Navy.

I would like to express my appreciation for the additional support of the Graduate School Research Fund of the University of Minnesota, and the Arctic Research Laboratory at Point Barrow, and its Director, Dr. Max C. Brewer. Thanks are also expressed to Dr. Keith M. Hussey of Iowa State University for kindly reviewing the manuscript.

\section{REFERENCES}

BRITTON, M. E., 1957. Vegetation of the Arctic Tundra. Arctic Biology, 18th Biology Colloquium: 26-62.

BRown, J., 1965. Radiocarbon Dating, Barrow, Alaska. Arctic, 18: 37-48.

CARSON, C. E., 1961. Evolution of Lake Basins in Arctic Alaska. Unpublished report, ONRAINA, Contract 236.

and K. M. HUSSEY, 1960. Hydrodynamics in Three Arctic Lakes. Journal of Geology, 68: 585-600.

and K. M. HUSSEY, 1961. Oriented Lakes of Arctic Alaska. Unpublished report, ONR-AINA, Contract 260.

and к. M. HUSSEY, 1962. The Oriented Lakes of Arctic Alaska. Journal of Geology, 70: 417-39.

FAIRBRIDGE, R. W., 1960. The Changing Level of the Sea. Scientific American, 202; 5: 70-79.

Hume, J. D., 1965. Sea Level Changes During the Last 2000 Years at Point Barrow, Alaska. Science, 150: 1164-66.

MOORE, G. W., 1960. Recent Eustatic Sea-Level Fluctuations Recorded by Arctic Beach Ridges. United States Geological Survey Professional Paper 400-B: B335.

PAYNE, T. G., et al., 1951. Geology of the Arctic Slope of Alaska. U.S. Geological Survey. Map OM-126. Oil and Gas Investigations.

PORTER, S. C., 1964. Late Pleistocene Glacial Chronology of Northcentral Brooks Range, Alaska. American Journal of Science, 262: 446-60.

SHEPard, F. P., 1964. Sea Level Changes in the Past 6000 Years: Possible Archeological Significance. Science, 143: 574-76. 